\title{
First record of Ephemeropsis, Coptoclava, Coleoptera inc. sed. and Turfanograpta from Lower Cretaceous paper-shales of the western-most site of Mongolia
}

\author{
Hellmut Jähnichen ${ }^{1}$ \& Eberhard Kahlert ${ }^{1}$
}

With 5 figures and 2 plates

\begin{abstract}
Nymph-fragments (and detached cerci) of the may-fly Ephemeropsis trisetalis Eichwald and the water-beetle Coptoclava longipoda Ping, a coleopteran and a shell-fragment of the conchostracan Turfanograpta sp. are described for the first time from Lower Cretaceous paper-shales of Bajan-Khongor, Mongolia. The assemblage Lycoptera (fishes included in the Order Osteoglossiformes, Fam. Lycopteridae)-Ephemeropsis-Coptoclava correlates with Lower Cretaceous deposits in Transbaikalia, Mongolia and North-Eastern China. The fern-species Adiantopteris sewardi (Yabe) Vassiljevskaja and Adiantopteris toyoraënsis (Oishi) Vassiljevskaja occur in fine-sandstones of Bajan-Khongor (Jähnichen \& Kahlert 1972). Their importance as Early Cretaceous flora-elements is discussed.
\end{abstract}

Key words: Ephemeropsis, Coptoclava, Turfanograpta, paper-shales, Lower Cretaceous.

\section{Zusammenfassung}

Larvenfragmente und isolierte Cerci der Eintagsfliege Ephemeropsis trisetalis Eichwald und vom Wasserkäfer Coptoclava longipoda Ping, und cin Schalenfragment der Conchostrake Turfanograpta sp. werden erstmalig aus unterkretazischen Dysodilen von Bajan-Khongor in der Mongolei beschrieben. Die Faunengemeinschaft Lycoptera (Fische der Ordnung Osteoglossiformes, Fam. Lycopteridae)-Ephemeropsis-Coptoclava tritt gleichzeitig in unterkretazischen Ablagerungen von Transbaikalien, Mongolei, und im nordöstlichen China auf. Das Vorkommen der Farnspezies Adiantopteris sewardi (Yabe) Vassiljevskaja und Adiantopteris toyoraënsis (Oishi) Vassiljevskaja in Feinsandsteinen von Bajan-Khongor (Jähnichen \& Kahlert 1972) und deren Wichtigkeit als unterkretazische Florenelemente werden diskutiert.

Schlïsselwörter: Ephemeropsis, Coptoclava, Turfanograpta, Dysodil, Untere Kreide.

\section{Introduction}

Comprehensive mapping of the geology and mineral ressources was carried out in the nineteen sixties by German geologists in Mongolia in the South-Changay-Plateau between the rivers Bajdaragin-gol and Taican-gol in the region of Bajan-Khongor.

A yellowish-grey, soft silty, limonitic fine grained sandstone and paper-shales were given to the authors for palaeobotanical investigations. From the weathered fine-sandstone a poorly preserved Early Cretaceous flora was described (Jähnichen \& Kahlert 1972). By contrast, the paper-shales produced no macro-palaeobotanical material, but did contain some fossil animal remains.
The thin, fine-splitting paper-shales are greybrownish, gypsum-efflorescences are destroying the sediment. According to Berkey \& Morris (1924/25) the paper-shales are limnic, semi-arid sediments deposited in salt-pans, flood-plains and near-shore layers.

The fossil remains of the paper-shales and argillites have been described from Transbaikalia (Turgino-Vitimskaja Svita), Mongolia (e.g., Ondai-Sair Formation) and the Jehol Beds of North-East China by many authors (e.g., Eichwald 1864, 1868, Müller In Middendorf 1848, Brauner et al. 1889, Handlirsch 1906-1908, Reis 1909, Berkey \& Morris 1924/25, Cockerell 1924, 1927, Ping 1928, Uéno 1935, Demoulin 1954, 1956, Novojilov 1957, 1960, Meschkova 1961, Ponomarenko 1961, Tschernova 1961, 1962, Jähnichen

\footnotetext{
${ }^{1}$ Museum für Naturkunde, Institut für Paläontologie, Invalidenstraße 43, D-10115 Berlin, Germany. Received October 1999, accepted January 2000
} 
\& Kahlert 1969, 1972. Tschernova \& Sinitschenkova 1974, Ponomarenko \& Popov 1976).

The Lycoptera-Ephemeropsis-Coptoclava assemblage correlates with Lower Cretaceous deposits from Transbaikalia (Turgino-Vitimskaja Svita), Mongolia (Ondai-Sair) and North-Eastern China (Jehol Beds) / (for details see Chang \& Jin 1996).

The studied material is deposited at the Institut für Paläontologie, Museum für Naturkunde der Humboldt-Universität, Berlin (MB).

\section{Systematic paleontology}

Order Ephemeroptera Haytt \& Arms. 1890

Family Hexagenitidae Lameère, 1917

Genus Ephemeropsis Eichwald. 1864

Type-Species: Ephemeropsis trisetalis Eichwald, 1864

Figs 1, 2, Pl. 1, Figs 1-4

\section{Synonyms}

1848 "Ephemera"-Neuropteren-Larve - Müller In Middendorf. A. Th.: 261. t. I(ii), fig. 7: Transbaikalia. Byrka. Lower Cretaceous.

1864 Ephemeropsis trisetalis - Eichwald: 19-21: Transbaikalia. Turgino-Vitimskaya Svita. Early Cretaceous.

1868 Ephemeropsis orientalis - Eichwald: 1192-1195, pl. 37. fig. 8: Transbaikalia, Lower Cretaceous.

1889 Ephemeropsis orientalis - Brauer. Redtenbacher \& Ganglbauer: 5. pl. 1. fig. 4a-d: Transbaikalia. Turga, Jurassic.

1908 Ephemeropsis trisetalis Eichwald - Handlirsch: 603. sine icon: Transbaikalia. Nertschinsk. Towega. Lower Cretaceous.

1908 Ephemeropsis middendorfi - Handlirsch: 604. sine icon. Transbaikalia. Byrka. Upper Jurassic.

1908 Ephemeropsis orientalis Eichwald - Handlirsch: 604. sine icon: Transbaikalia. Turga, Upper Jurassic.

1908 Phacelobranchus braueri Handlirsch: 604. 1. 46. fig. 33: Transbaikalia, Turga. Upper Jurassic.

1909 Ephemeropsis orientalis Reis: Transbaikalia. Upper Jurassic.

1924 Ephemeropsis trisetalis Eichwald -- Cockerell: 137. pl. 1, figs 1-9. text-figs 2-4: Mongolia. Onda-Sair Formation. Lower Cretaceous.

1924 Ephemeropsis melanurus Cockerell: 139. pl. 1. fig. 10: Ondai-Sair. Lower Cretaceous.

1928 Ephemeropsis trisetalis Eichwald - Ping: 38. figs 17-18. pl. 2. figs 1-2: North-Eastern China. Jchol Beds. Lower Cretaceous.

1935 Ephemeropsis trisetalis Eichwald - Uéno: fig. 1. t. I-III Jehol Beds, Lower Cretaceous.

1956 Ephemeropsis trisetalis Eichwald - Demoulin: 5. fig. 1 (reconstruction). Jurassic.

1961 Ephemeropsis trisetalis Eichwald - Tschernova: 862. figs $2-6$. pl. 1. fig. 1: pl. 2. fig. 1: Transbaikalia, Lower Cretaceous.

1961 Ephemeropsis trisetalis Eichwald - Meschkova: 164. figs 1-3: Transbaikalia. Turgino-Vitimskaya Svita. Lower Cretaceous.

1962 Ephemeropsis trisetalis Eichwald - Tschernova In Osnowy paleontologii 9: 58-59. text-figs 64 and 66. pl. 1. figs $1-3-$ Transbaikalia. Jurassic.
1970 Ephemeropsis trisetalis Eichwald - Semaka: 456, tab. 2 (only mentioned in a flora-list); North-Korea, Prov. North Huanghe, Hanpo Beds, Loc. Kymchon, Upper Cretaceous.

1992 Ephemeropsis trisetalis Eichwald - Carpenter: 20, fig. $14 / 6 a-c$.

Material: MB. J. 1788-1790: Two nymph-fragments and five larvae irregularly embedded and with detached cerci from Lower Cretaceous paper-shales of Buriduin-gol, BayanKhongor, Mongolia. This is the western-most occurence for this taxon.

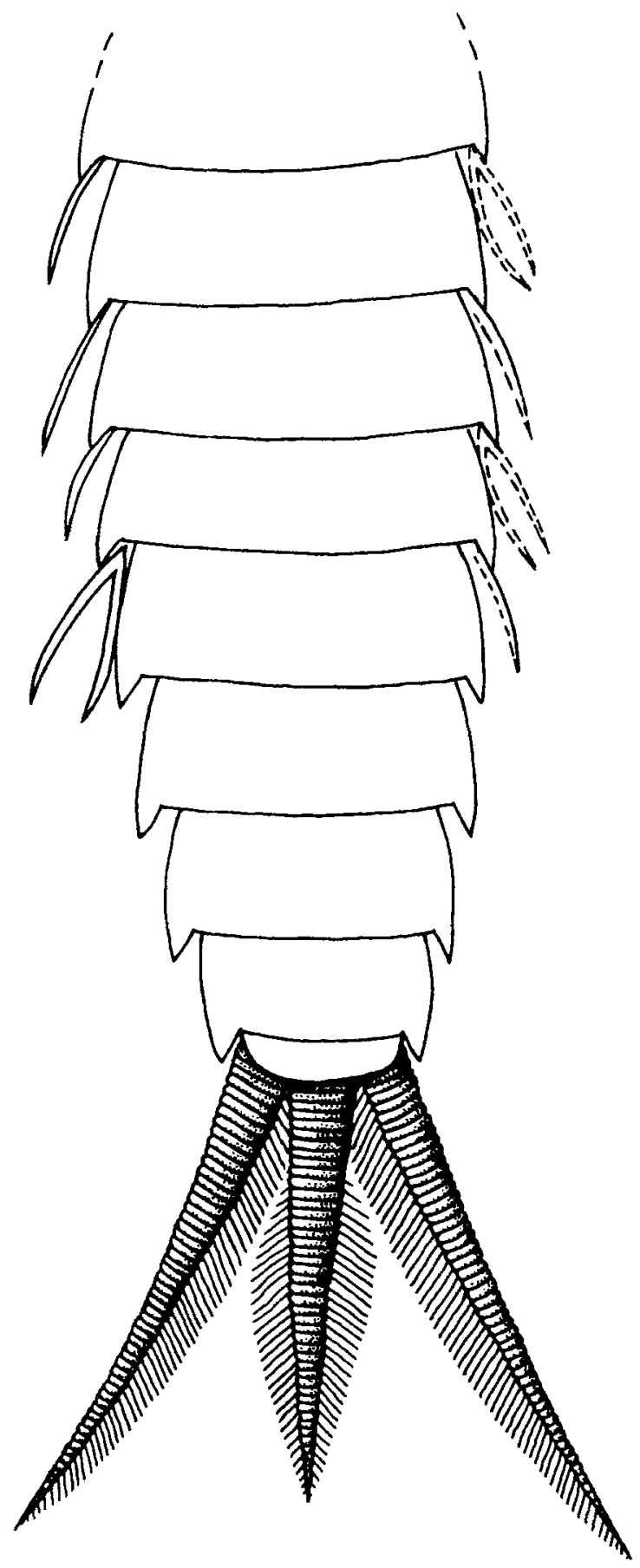

Fig. 1. Nymph-fragment of Ephemeropsis trisetalis Eichwald, Bayan-Khongor, Mongolia (MB. J. 1788) 


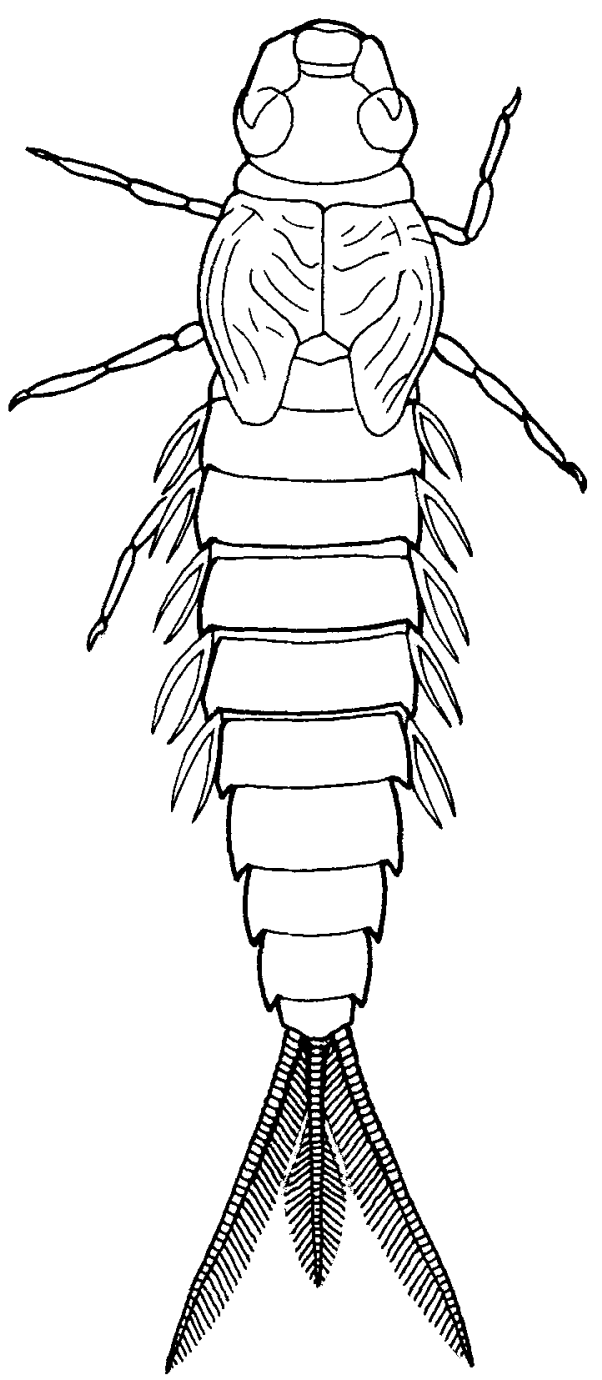

Fig. 2. Ephemeropsis trisetalis Eichwald, Transbaikalia, Turgino-Vitimsk Svita (after Meschkova 1961: fig. 2)

Description: Nymph-fragments without cephalon, thorax and extremities, consisting of five specimens irregularly embedded on a small area $60 \times 30 \mathrm{~mm}$. The best preserved specimen contains eight abdominal segments with traces of tracheal gills along the sides of the abdomen and has three cerci (Pl. 1, Fig. 1). The abdominal segments are $39,5 \mathrm{~mm}$ long, the lateral cerci are $12,5 \mathrm{~mm}$ in length, and the paracercus is $11,0 \mathrm{~mm}$ long. Detached cerci are also preserved. The laterals are provided with ciliae only on the inner side, while the paracercus is ciliated on both sides. The ciliae are typically $1,8 \mathrm{~mm}$ long (P1. 1, Figs 2-4).

Further occurrence: According to Ponomarenko (pers. comm. 1974) Ephemeropsis trisetalis was collected in 31 localities of the Transbaikalia- and Amur-Region, in seven localities of North-East- and Central Mongolia, and also in seven localities of North- and East China.
Comments: Ephemeropsis trisetalis was established by Eichwald (1864) on the basis of material from the Turgino-Vitimskaya Svita of Transbaikalia. Further studies have confirmed the presence of E. trisetalis from Mongolia and North-Eastern China, see reference in the synonymy-list. After comprehensive studies of about 1700 fossil larvae from Transbaikalia and Mongolia Meschkova (1961) produced a reconstruction of the nymph indicating the cephalon, thorax, segments, extremities and tracheal gills. In addition, she discovered that the deeply split tracheal gills (Demoulin 1956) have a different exterior shape directly depending on favourable conditions of preservation. In fine-grained material the gills have a shallow, leaflike shape, but in our material only traces of the exterior and inner margins of the gills are preserved (Figs 1-2).

Tschernova \& Sinitschenkova (1974) first illustrated the full venation of the front wing of E. trisetalis from the Turgino-Vitimsk Svita of Transbaikalia.

Tschernova (1961) confirmed the inclusion of Ephemeropsis trisetalis within the family Hexagenitidae Lamere, 1917, as already postulated by Demoulin (1954), because the Early Cretaceous specimens are essentially different from members of the Paedephemeridae.

\section{Order Coleoptera Linné 1758}

Family Coptoclavidae Ponomarenko, 1961

Genus Coptoclava Ping, 1928

Type species: Coptoclava longipoda Ping, 1928

Fig. 3, Pl. 2, Fig. 1

\section{Synonyms}

1928 Coptoclava longipoda - Ping: 39, figs 19-20; pl. 2 , figs 3-4; North-Eastern China, Shantung Province, Laiyang-Formation, Lower Cretaceous.

1961 Coptoclava longipoda Ping -- Ponomarenko: 67-72, figs 1-6; Transbaikalia, Turgino-Vitimsk Svita, Lower Cretaceous.

Material: MB. J. 1793: One fragment with counterpart from Lower Cretaceous paper-shales of Buriduin-gol, BayanKhongor, Mongolia. This is the western-most occurrence for this taxon.

Description: A single nymph-fragment with counterpart containing six and four ventral segments, $9 \mathrm{~mm}$ in length. Tergites strongly sclerotisized. From the last reduced segment two sagittiform chitinized urogomphi extend over $5 \mathrm{~mm}$ in length. Between the last two segments traces of a tracheal trunk are represented by two lines without spiral thickenings, as in the reconstruction by Ponomarenko (1961: fig. 5) (Fig. 3, Pl. 2, Fig. 1). 


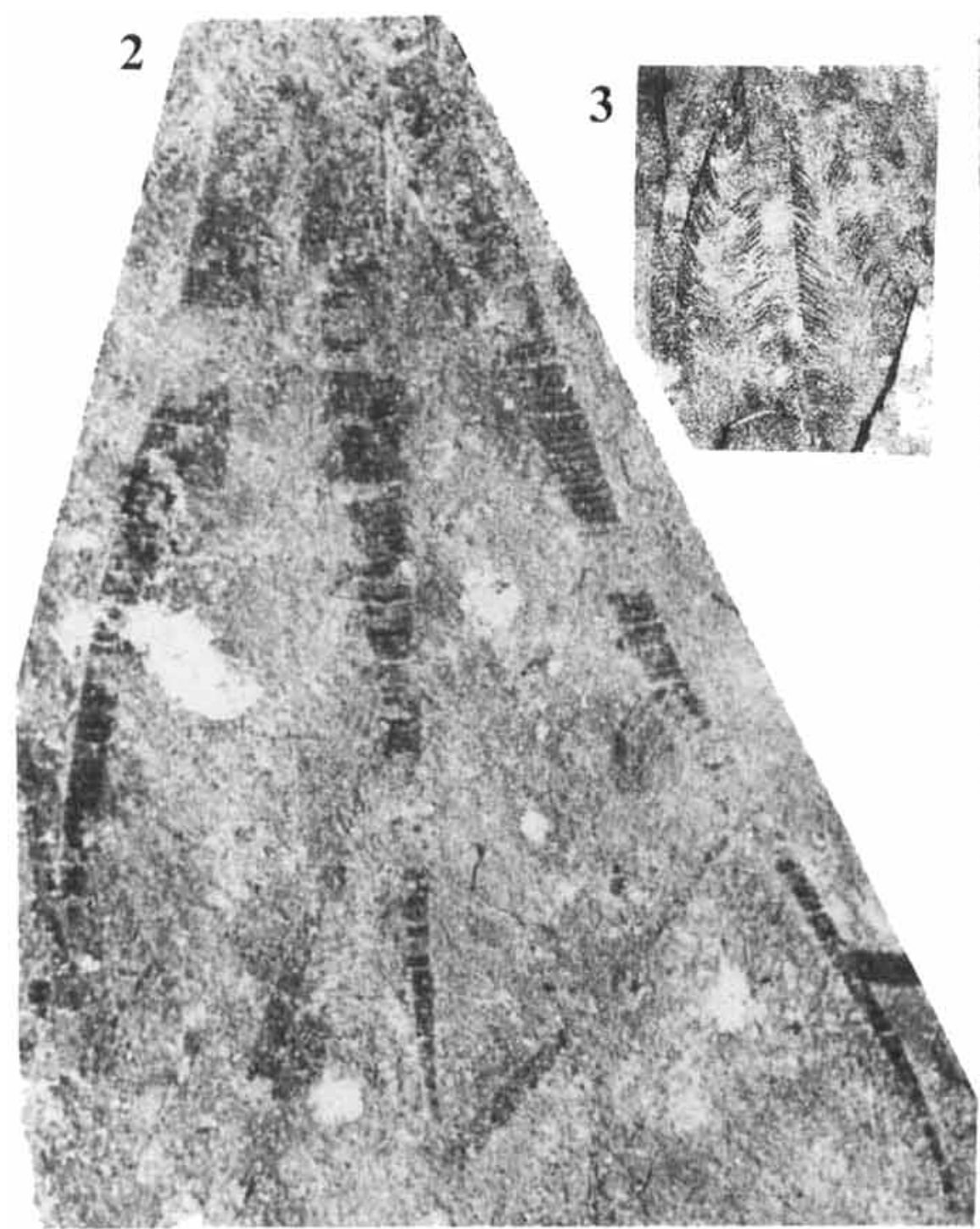

4

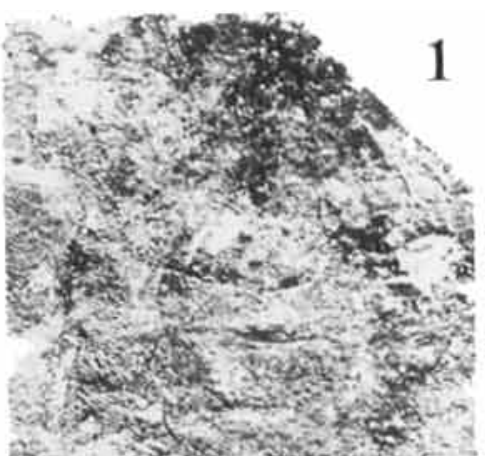

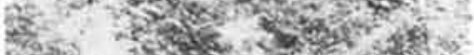
Ni) $\rightarrow$ X

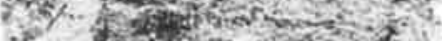
$2, b$,

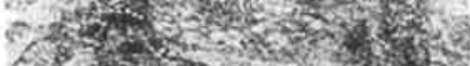

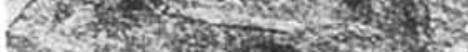

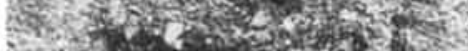
1)

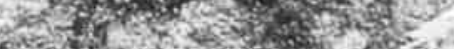
(1)

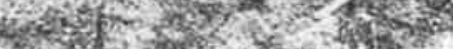

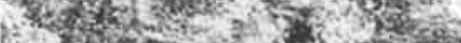
S.

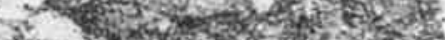

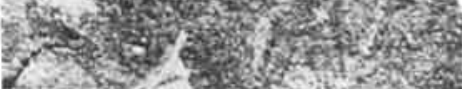

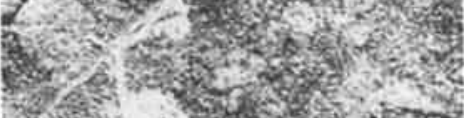

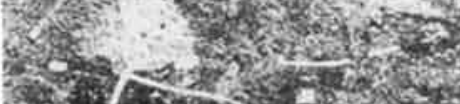

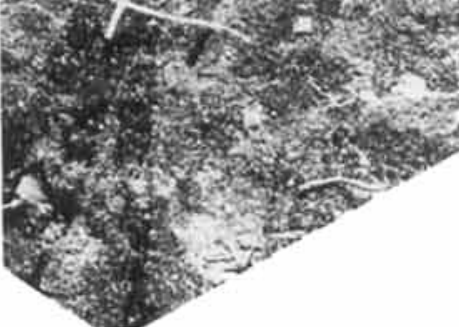

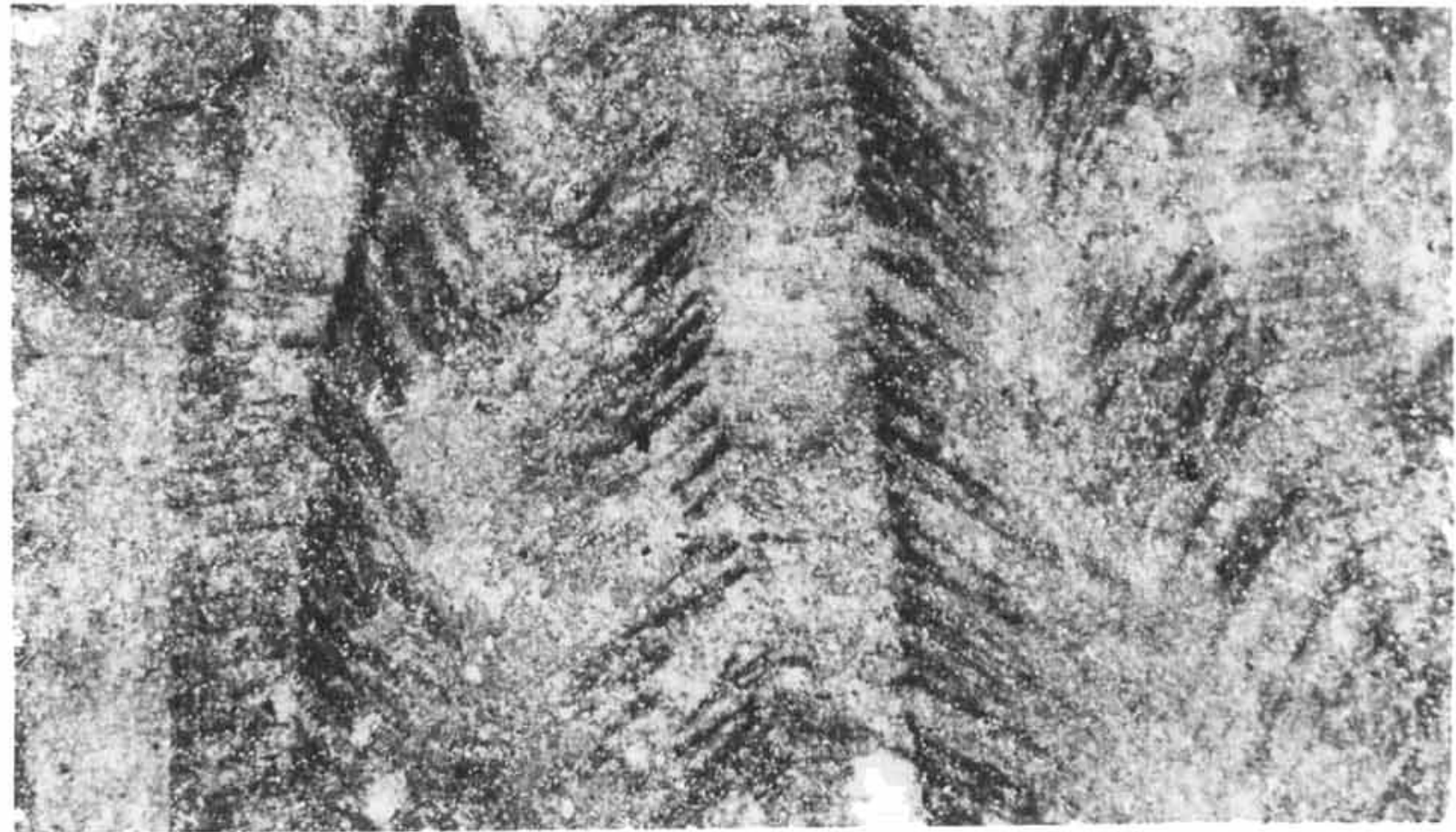




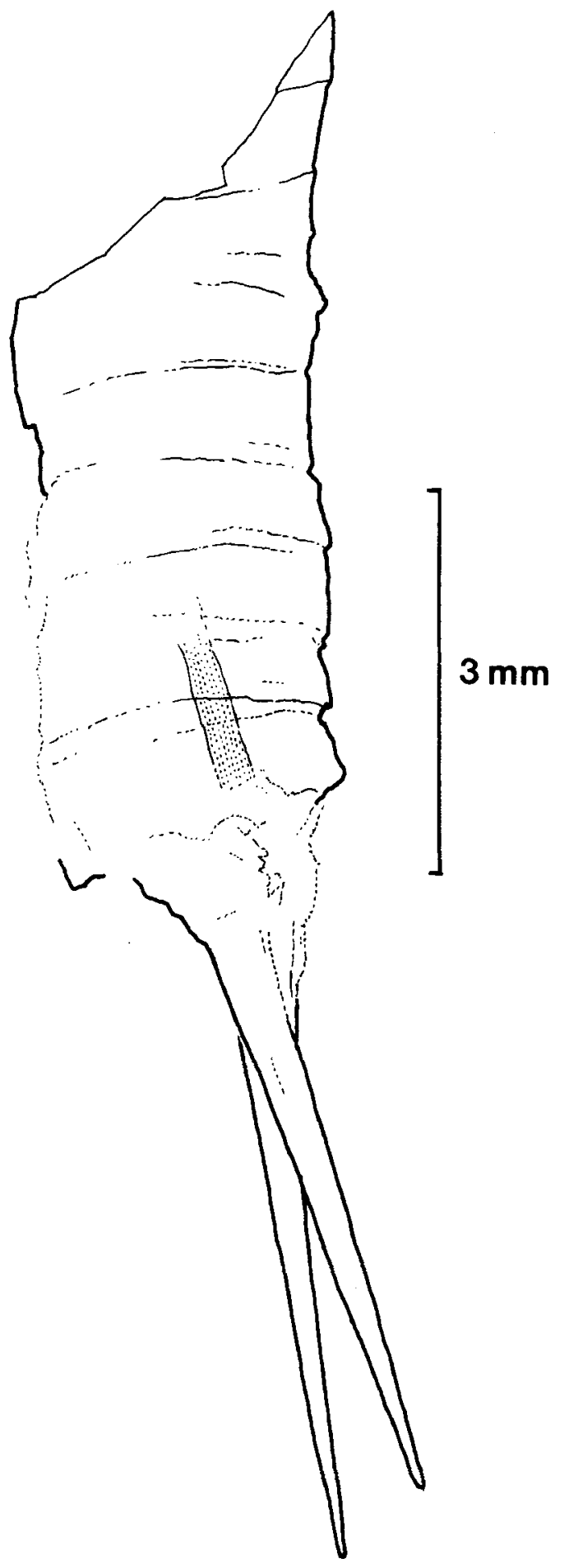

Fig. 3. Coptoclava longipoda Ping, nymph-fragment with seven ventral segments, between the last two segments traces of a tracheal trunk preserved by two lines, two sagittiform urogomphi, Mongolia (MB. J. 1793)
Comments: The genus Coptoclava with a single species, $C$. longipoda, was established and described by Ping (1928) from the Lower Cretaceous Laiyang-Formation of Shantung Province, North-Eastern China. After comprehensive investigations of 221 specimens from the TurginoVitimsk Svita of Tansbaikalia and 7 specimens from the Ondai-Sair Formation of Mongolia Ponomarenko (1961) presented a complete description of $C$. longipoda. This included the body structure of the full imago containing mandibulae, thorax, ventral segments, extremities, a complex tracheal-system and urogomphi. The middle and hind legs were used as swimming-rowing and the fore legs as catching organs. Growthstages of larvae were distinguished.

According to Ponomarenko (1961: 72) "the nymphs of Coptoclava longipoda were restricted to lakes with sapropelitic soils and sparse vegetation. Larvae of Coptoclava concurrently occur with nymphs of Ephemeropsis trisetalis, the latter possibly serving as nutriment for the former".

\section{Coleoptera inc. sed.}

Fig. 4, Pl. 2, Fig. 4-5

Material: MB. J. 1791: A single imprint with counterpart from Lower Cretaceous paper-shales of Buriduin-gol, BayanKhongor, Mongolia. This is the western-most occurrence for this taxon.

Description: Body with a straight-ovulate shape, $3 \mathrm{~mm}$ in length and $1,7 \mathrm{~mm}$ in width. Head deeply withdrawn in the pronotum. Eyes probably flat. Both first members of the antennae are relatively thick, curved outwards and nearly twice as long as thick. Their length corresponds to the distance between the attachment positions on the head. The pronotum is a little broader than long, with the greatest width in the centre. The pronotum tapers weakly both anteriorly and posteriorly. On the upper side there are recognizable structures.

The elytra are $0,8 \mathrm{~mm}$ long, and are distinctly broader than the base of the pronotum. The angle of the shoulder observable, in the first fifth part with 3-4 longitudinal ribs (Fig. 4, Pl. 2, Figs $4-5)$.

Plate 1, Figs 1-4. Ephemeropsis trisetalis Eichwald from Lower Cretaceous paper-shales of Buriduin-gol, Bayan-Khongor, Mongolia. 1. Nymph-fragment with seven abdominal segments, tracheal gills and cerci. MB. J. 1788, $\times$ 4. 2. Detached striated cerci (cp. Eichwald, 1868: 1192; genus-diagnose of Ephemeropsis "... tres setas articulatas respiratorias et ciliis ornatas gerentibus"). MB. J. $1789, \times 8.3$. Detached ciliated cerci, laterals on the inner side and the paracercus on both sides. MB. J. 1790, $\times 4,5.4$. Detached ciliated cerci, laterals on the inner side and the paracercus on both sides. MB. J. $1790, \times 18,4$ 


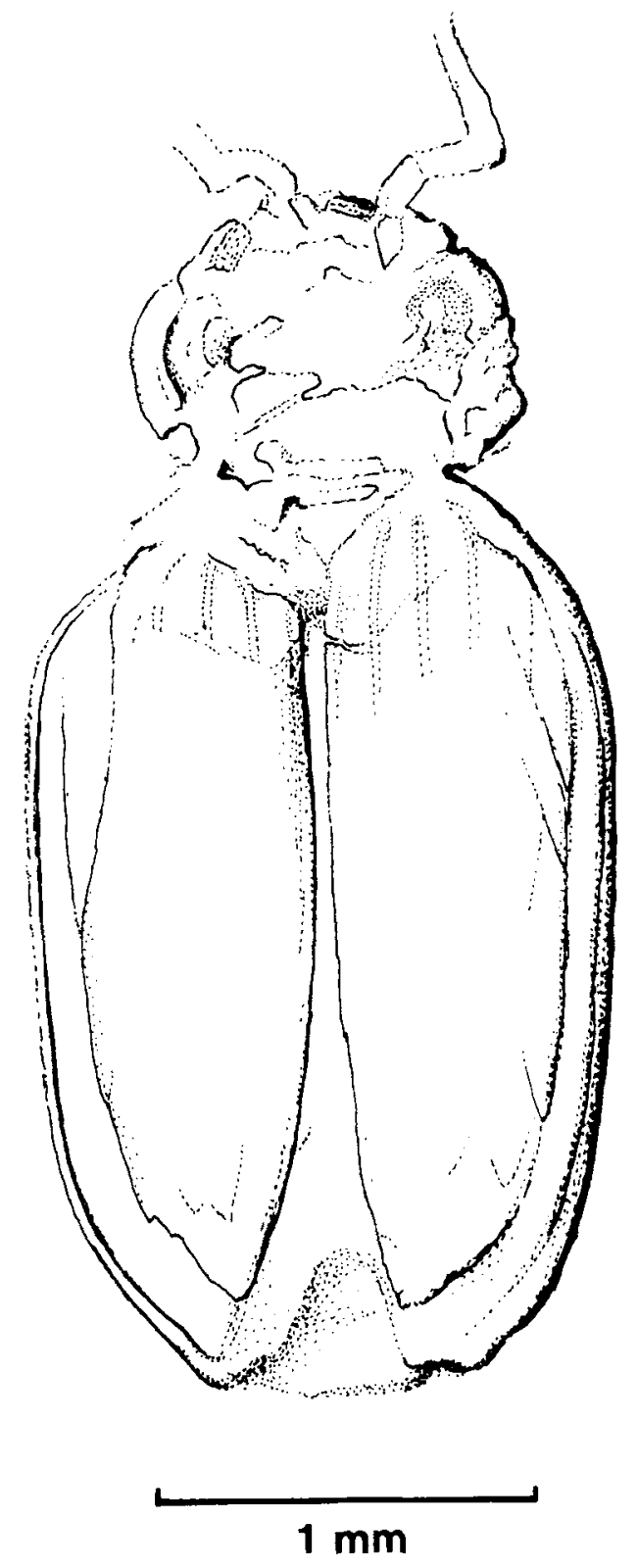

Fig. 4. Coleoptera inc. sed.. head deeply withdrawn in the pronotum, with traces of two antennae. Mongolia (NB. J. 1791)

Comments: Since coxae and legs are not preserved, the taxonomic position of this specimen could not be assigned. On the basis of the morphological features of the pronotum and the elytra the specimen may belong to the Heteromera or Malacodermata, perhaps demonstrating an in- termediate position between the archaic Cupediformes and the two previously mentioned groups (F. Hieke, pers. comm. 1969).

Order Conchostraca Sars, 1867

Family Cyzicidae Stebbing, 1910 emend. Barnard, $1929=$ Bairdestheriidae Novojilov, 1954

Genus Turfanograpta Novojilov, 1957

\section{Turfanograpta sp.}

Fig. 5A, B, Pl. 2, Figs 2-3

Material: MB. J. 1792: A single shell-fragment from Lower Cretaceous paper-shales of Buriduin-gol, Bayan-Khongor, Mongolia. This is the western-most occurrence for this taxon.

Description: Only one small, thin shell-fragment with about 13 growth-lines, measuring $12 \mathrm{~mm}$ long by $7,5 \mathrm{~mm}$ high. Growth-lines at the top more widely spread, subsequently are densely arranged. The most important morphological character are the dense, radially arranged long-fibrous striae branching off and linking together resulting in a longitudinal irregular netlike structure. This very characteristic ornamentation corresponds to the genus-diagnosis for Turfanograpta given by Novojilov (1957: 237, fig. 1), however, the presence of tubercles ("usually with a short spine") on the margins of the growth-lines can not be confirmed (Fig. 5, Pl. 2, Figs 2-3).

Comments: Within the Palaeontological Atlas of North-East China (1980: 71-72, pl. 34, figs 1-3) two new species are described as Turfanograpta dichoformis and T. filiformis Wang from the Dalazi-Formation of Yanji (former Jehol Province). The fine ornamentation of the latter is identical to that of $T$. chowmincheni from Sinkiang and the new material from BayanKhongor, Mongolia. But the real organic nature and presence of tubercles ("tumorlike" spines) were not acknowledged by Wang who assumed "... the latter may be fibrous structures of the retained valves leading to somewhat irregular marginal sculpture".

Plate 2, Figs 1-5. Water-beetle, coleopteran- and conchostracan remains from Lower Cretaceous paper-shales of Buriduin-gol, Bayan-Khongor, Mongolia. 1. Coptoclava longipoda Ping. nymph-fragment with six ventral segments, tergites strong sclerotisized and two sagittiform urogomphi. MB. J. 1793. $\times$ 8.5. 2. Turfanograpta spec., with dense radially arranged long-fibrous striae in the intervals. MB. J. 1792, $\times$ 16. 3. Turfanograpta sp. one single shell-fragment with ca. 13 growth-lines. MB. J. 1792, $\times$ 6. 4-5. Coleoptera inc. sed. With counterpart. head deeply withdrawn in the pronotum, with two preserved antennae, recognized structures on the counterpart. MB. J. 1791. $\times 32$

Fig. 5. Turfanograpta spec. from Mongolia. A. Shell-fragment with radially arranged growth-lines, $\times 10$. B. With dense, radially 


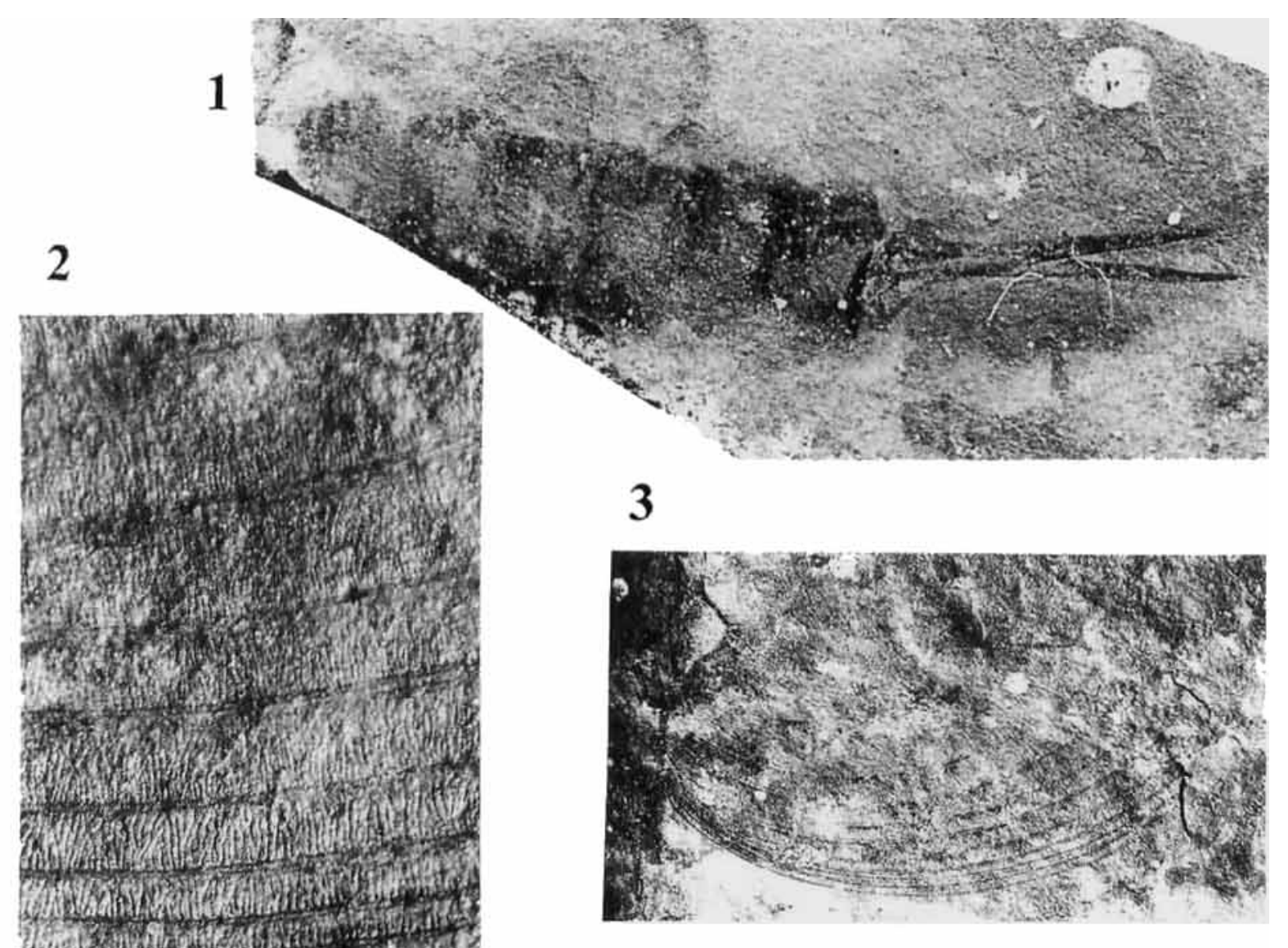

5
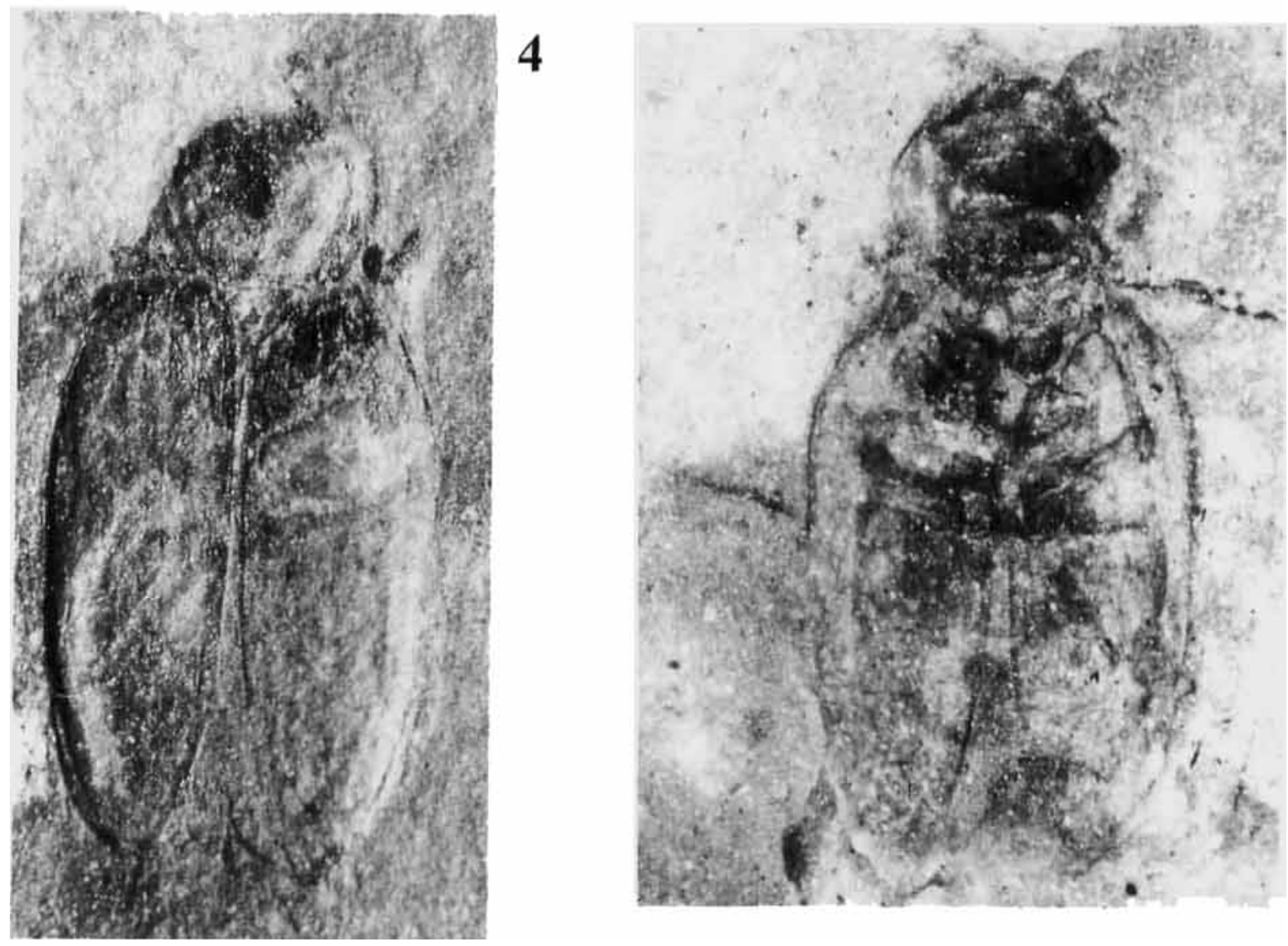


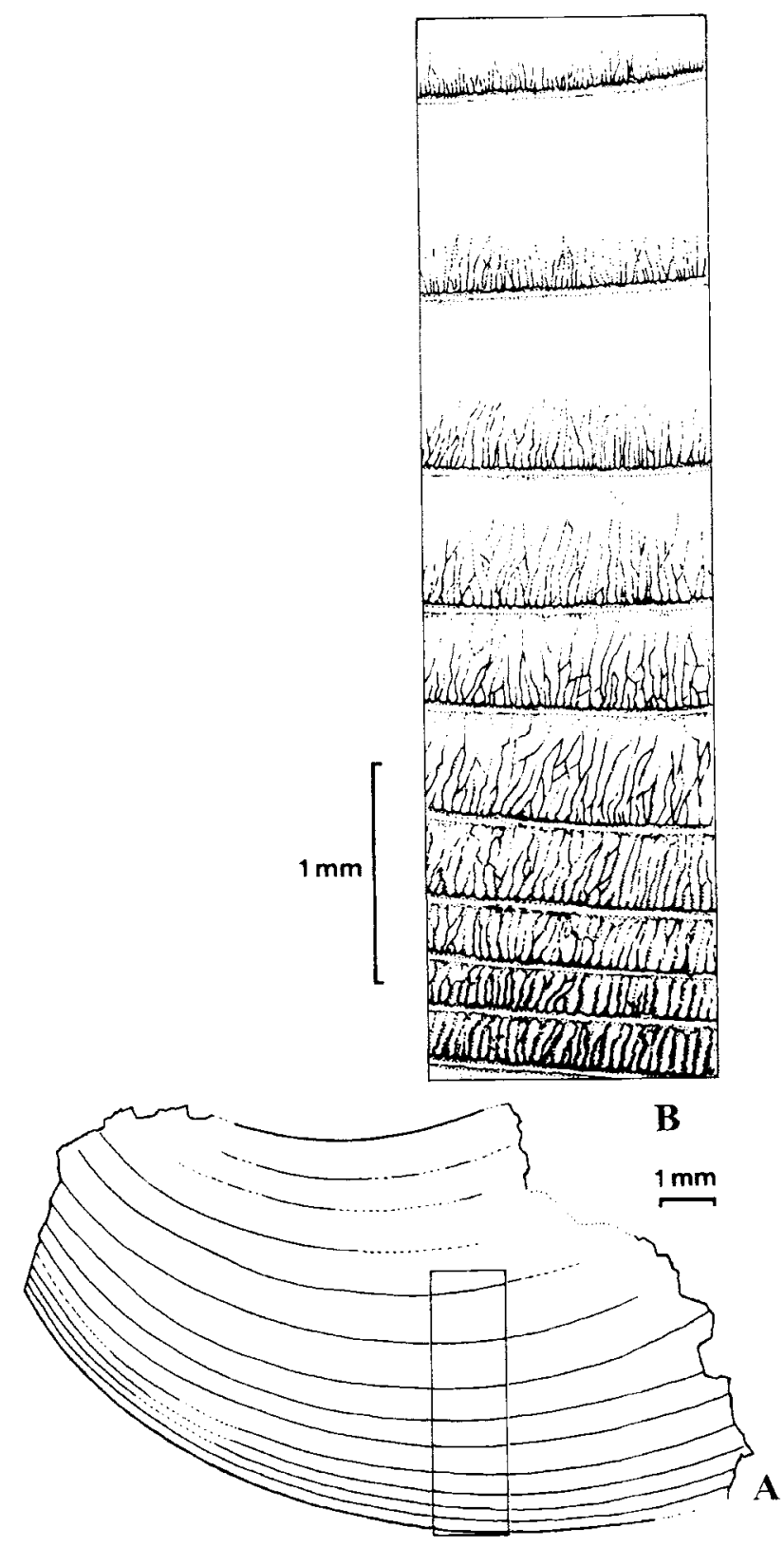

arranged long-fibrous striae in the intervals. Mongolia (MB. J. 1792)

In terms of their morphological features Turfanograpta dichoformis and T. filiformis are very similar, and the latter may belong within the range of Turfanograpta chowmincheni. Therefore, Turfanograpta chowmincheni is the first record from North-Eastern China as Turfanograpta sp. from the western-most site of Mongolia. Together with the records from Sinkiang the known geographic range is significantly enlarged.

Turfanograpta spec. is thus recognised here as a new associate of the Lycoptera-EphemeropsisCoptoclava assemblage from the Lower Cretaceous of Mongolia as Turfanograpta chowmincheni from North-Eastern China.
It is interesting that according to Ponomarenko (pers. comm. 1974) “... not a single specimen of Turfanograpta within several thousands of conchostracan shells has been determined from the Lower Cretaceous deposits of Mongolia".

\section{Stratigraphy}

Concerning the stratigraphical correlation of the paper-shales at Bayan-Khongor of the So'géyChundey-Basin, the Early Cretaceous flora (Jähnichen \& Kahlert 1972) of the fine-grained sandstones from the same "Limnic Series" is highly significant. Recent understanding of Adiantopteris ("Adiantites") sewardi (Yabe) Vassiljevskaja and Adiantopteris toyoraënsis (Oishi) Vassiljevskaja which thought to be only accessories, are very important components of an Early Cretaceous flora, which is found in Eastern Siberia, Southern Primorje, the South Eastern Korean Peninsula, Japan and Mongolia.

Lena-Basin (Middle Section): Batylyk and Eksenjakh Svita, Berriasian-Barremian, Aptian (Vakhrameev 1958, Kimura 1979, Ohana \& Kimura 1995). Southern Primorje (former NikanSeries), Ussury Bay (Kryštofovič \& Prinada 1932: 367); in the Sufjun-Basin with Ussury-, Lipovets- and Galenkov Svita; Barremian, Aptian, Albian (Krasilov 1967, Kimura 1979, Ohana \& Kimura 1995). South Eastern Korea Peninsula: former Naktong Beds (Yabe 1905, Oishi 1940); now Sindong-flora (Chang 1985, 1988 non vidimus In Ohana \& Kimura 1995) Valanginian-Barremian (Ohana \& Kimura 1995, Kimura 1979). Japan: Kiyoshué-Formation (Type-sequence for Adiantopteris toyoraënsis, Berriasian (Kimura 1979. Ohana \& Kimura 1995), Toyora District, Yamaguchi Prefecture; Oguchi-Formation, Berriasian-Valanginian (Ohana \& Kimura 1995), Central Honshu. Tetori-flora, Inner Zone of Japan (Yabe 1905, Oishi 1940). Akaiwa-Formation, Hautérive-Barremian (Kimura \& Hirata 1975, Ohana \& Kimura 1995), Central Honshu, Tetoriflora (Kimura \& Sekido 1976, 1978). Tokura-Formation. Berriasian-Barremian (Kimura et al. 1979), Tetori-flora, North-Eastern Honshu, Gumma Prefecture. Ryošeki-Formation, BerriasianValanginian: Lower Monobegawa-Formation, Hautérive-Barremian; Upper Monobegawa-Formation, Aptian-Albian (Kimura \& Hirata 1975, Kimura 1979, Ohana \& Kimura 1995). Choshi Peninsula, Aptian (Nishida 1960 In Kimura \& Hirata 1975: 77, Ohana \& Kimura 1995), Chiba Prefecture. 
From this check-list it is evident that Adiantopteris sewardi ranges from Berriasian to Albian. In the Oguchi-Akaiwa- and Tokura-Formations it is common to very abundant from Berriasian to Barremian times. Therefore, the paper-shales of Bayan-Khongor may probably range from Berriasian to Barremian in age. W. Krutzsch (1970; In Abschlußbericht ... p. 638-643) analysed the palynoflora of different arenaceous lignites and clays from the south-western part of the Bumbuger Basin ("Lower Limnic Series") and reported an Ephedreaceae-Conifer-Angiosperm community with an admixture of Hystrichosphaeroideae. On the basis of the presence of different angiosperms (fam. indet.) Krutzsch postulated a Cenomanian age, but probably ranging down to the Albian and also up to the Turonian and possibly even to Conacian.

In any case we are dealing here with a younger sequence than in the paper-shales of the So'géy-Chundey-Basin. Last but not least E. Herrig, Greifswald, (1970 In Abschlußbericht ... p. 647-652) gave a very interesting account of two samples of limestone-bearing schists from the paper-shales-facies of the So'géy-ChundeyBasin, in the Western area of the Buriduin-gol. In these samples there is a great predominance of Cypridea ex gr. bispinosa Galeeva, associated with Cypridea spinigera Ljubimova, Darwinula tubiformis Ljubimova, Darwinula contracta Mandelstam and Lycopterocypris debilis Ljubimova.

This ostracode-assemblage was correlated with the Dzunbain subsvita ("Dark-grey series") of Eastern Mongolia, probably of Barremian age (Ljubimova 1956).

\section{Acknowledgements}

We are much indebted to A. G. Ponomarenko, Moscow, for important and valuable informations as well as to our colleague, F. Hieke, Berlin, for the morphological analysis of the coleopteran. Our warmest thanks to Tatsuaki Kimura and his school (Tokyo), an outstanding specialist of the mesophytic flora, especially for his comprehensive studies concerning phytogeography in the whole Far East including Indo-Malaysia. Without his publications our stratigraphical problems could not be solved. Further, we thank Zhang Jiang-Young (Beijing) for his translation of a Chinese text dealing with Turfanograpta into English. Our best appreciation to Dave Unwin for checking through and revising our English text. For photo-documentation and drawings we would like to express our sincere thanks to Mrs. Waltraud Harre and Mr. Jörg-Peter Mendau, both at the Museum für Naturkunde, Berlin.

\section{References}

Abschlussbericht über die Karticrungs-Sucharbeiten Teil 1. Text-Band Teil 3 zum Geologischen Bau und Bodenschätzen der MVR. - VEB Geologische Forschung und Erkundung Halle 1970 (bis 1989 "Vertrauliche Verschlusssache").

Berkey, Ch. P. B. \& Morris, F. K. 1924/1925. Basin structures in Mongolia. - Bulletin of the American Museum of Natural History 41: 103-127.

Brauer, F., Redtenbacher, J. \& Ganglbauer, L. 1889. Fossile Insekten aus der Jura-Formation Ostsibiriens. - Mémoires de l'Académie Impérial des Sciences, VII ${ }^{\circledR}$ Série, 36 (15): 4-6.

Carpenter, F. M. 1992. Fam. Hexagenitidac. 1. In Kaesler, R. L. \& Moore, R. C. (eds). Treatise on Invertebrate Paleontology, Part R, Arthropoda 4,3: 19-26. The Geological Society of America Inc. and the University of Kansas; Boulder, Colorado and Lawrence, Kansas.

Chang K. H. 1985. Synopsis of Cretaceous stratigraphy of Kyogsang Basin - with special reference to 'syntectosome', a new concept. - Journal of Natural Sciences. Kyungpook University 3: $89-101$.

- 1988. Cretaceous strata. In Lee, D. S. (ed.). Geology of Korea. Kyohak-sa, Seoul: 176-194.

Chang Mee-mann \& Jin Fan 1996. Mesozoic fish faunas of China. In Arratia, G. \& Viohl, G. (eds). Mesozoic fishes - Systematics and Paleoecology: 461-478, Verlag Dr. Pfeil, München.

Cockerell, T. D. A. 1924. Fossils in the Ondai-Sair-Formation. Mongolia. - Bulletin of the American Museum of Natural History 51 (6): 129-144.

- 1927. New light on the giant May-flies of Mongolia. American Museum, Novitates 244: $4 \mathrm{pp}$.

Demoulin, G. 1954. Les Ephéméroptères jurassiques du Sinkiang. - Bulletin et Annales Société Entomologique de Belgique 11-12: 322-326.

- 1956. Le "Mystère" des Ephemeropsis (Ephéméroptères jurassico-crétacés d'Asie paléarctique). - Bulletin de l'Institut Royal des Sciences Naturelles de Belgique 32 (53): 8 pp.

Eichwald, E. D. 1864. Sur un terrain jurassique à poissons et insects d'eau douce de la Sibérie orientale. - Bulletin de la Société géologique de France (2) 21: 19-21.

- 1868. Lethaea rossica ou Paléontologie de la Russie décrite et figurée. - II(b): $1192-1195$ et Atlas. E. Schweizerbart, Stuttgart.

Handlirsch, A. 1906-1908. Die fossilen Insekten und die Phylogenie der rezenten Formen. 1430 pp. Wilhelm Engelmann, Leipzig.

Jähnichen, H. \& Kahlert, E. 1969. Nachweis einer Insektenfauna aus vermutlich jurassischen paper-shales der Mongolischen Volksrepublik. - Unveröffentlicher Bericht. Museum für Naturkunde der Humboldt-Universität zu Berlin: 1-9.

- 1972. Über eine mesozoische Flora aus der Mongolischen Volksrepublik. - Zeitschrift Geologie 21(8): 964-1001.

Kimura, T. 1979. Notes on the Cretaceous floristic provinces in East Asia. - Fossils (Kaseki) 29: 79-95. (Japan).

Kimura, T. \& Hirata, M. 1975. Early Cretaceous plants from Kochi Prefecture, Southwest Japan. - Memoirs of the National Science Museum of Japan 8: 67-90.

Kimura, T., Saito, S. \& Tojo, T. 1979. Early Cretaceous plants from the Tokurazawa Formation, Gumma Prefecture, in the Inner Zone of North-East Japan. - Transactions and Proceedings, Palaeontological Society of Japan, New Serie 114: $87-96$.

Kimura, T. \& Sekido, S. 1976. Mesozoic plants from the Akaiwa Formation (Upper Neocomian), the Itoshiro Group, Central Honshu, Japan. - Transactions and Proceedings, Palaeontological Society of Japan, New Serie 103: 343-378. 
- 1978. Addition to the Mesozoic plants from the Akaiwa Formation (Upper Neocomian). the Itoshiro Group. Central Honshu, Inner Zone of Japan. - Transactions and Proceedings. Palaeontological Society of Japan. New Serie 109: $259-279$.

Krasilov. V. A. 1967. Rannemelowaja flora juschnogo Primorja i ejo značenie dlja stratigrafii. 364 pp. Akademija Nauk SSSR. Dalnewostočnyi Geologičeskii Institut. Idatelstwo "Nauka". Moskwa.

Kryschtofovitsch. A. N. \& Prinada. W. D. 1932. Materialv k mesozoikoi flore Ussurijskovo kraja. - Izvestija Vsesojusnovo geologo-razvodotschnovo objedilenija 2 . wpusk 28 : 363-373. Moskva.

Ljubimova. P. S. 1956. Ostracody melowych obloscheni wostočnoi časti Mongolskoi Narodnoi Respubliki i ich značenie dlja stratigrafii. - Trudy VNIGRI. Nowaja Serija 93: 174 pp. Leningrad.

Meschkova, N. P. 1961. O ličinkach Ephemeropsis trisetalis Eichwald (Insecta). - Paleontologičeskii Zhurnal 4 $164-168$.

Müller. J. 1848. In Middendorf. A. Th. Reisen in den äußersten Norden und Osten Sibiriens während der Jahre 184.3 und 1844. 1 (1): 260-263. Kaiserliche Akademie der Wissenschaften. St. Petersbourg.

Novojilov. N. I. 1957. Crustacés bivalves de lordre des Conchostracés du Crétacé inférieur chinois et africain. - Annales de la Societé géologique du Nord 77: $235-243$.

- 1960). Suborder Conchostraca. Fam. Bairdestheriidae. Fig. 535. Pl. 15. Figs 3-4. In Tschernyschewa. N. E. (cd.) Osnovy paleontologii 8: 238-240. Moskra.

Ohana, T. \& Kimura. T. 1995. Late Mesozoic phytogeography in Eastern Eurasia. with special reference to the origin of angiosperms in time and life. - Proceedings of the $15^{\text {th }}$ International Symposium of Kvungpook National University: $293-328$

Oishi. S. 1940. The Mesozoic floras of Japan. - Journal of the Faculty of Science. Hokkaido Imperial University. Ser. 4. 5. No. 2-4: 123-480.

Palaeontological Atlas of North-East China (1980): 71-73 Shenjang. Institute of Geology and Mineral Ressources. Geological Publishing House. Beijing.

Ping. C. 1928. Cretaceous fossil insects of China. - Palaeontologica Sinica. Serie B 13 (1): 56 pp.. Geological Survey of China. Peiping.
Ponomarenko, A. G. 1961. O sistematičeskom poloschenii Coptoclava longipoda Ping (Insecta, Coleoptera). - Paleontologičeskii Zhurnal 1961 (3): 67-72.

Ponomarenko. A. G. \& Popov, Y. A. 1976. Mestonachoschdenija ostatkow wymerschich nasekomych na territorii Mongolskoi Narodnoi Respubliki. - Akademija Nauk SSSR, Paleontologija i Biostratigrafija Mongolii. Trudy, wypusk 3: 137-144. Isdatelstwo "Nauka". Moskva.

Reis. O. 1909. Die Binnenfauna der Fischschiefer in Transbaikalien. - Recherches géologiques et minières le long du chemin de fer de Sibérie 29: $68 \mathrm{pp}$.

Semaka. A. 1970. Einige fossile Pflanzen aus der Koreanischen Volksdemokratischen Republik. - Zeitschrift Geologie 19 (4): $456-468$.

Tasch. P. 1969. Conchostraca, Fam. Cvzicidae. In Moore, R. C. \& Teichert. C. (eds). Treatise on Invertebrate Paleontology, Part R. Arthropoda 4 (1): 151-153, The Geological Society of America Inc. and University of Kansas.

Tschernova. O. A. 1961. O sistematičeskom poloschenii i geologičeskom wozrastje podenok roda Ephemeropsis Eichwald (Ephemeroptera. Hexagenitidae). - Entomologičeskoje obozrennije 40 (4): 858-869, St. Petersburg.

- 1962. Ordo Ephemeroptera, Fam. Hexagenitidae. In Rodendorf. B. B. (ed.). Osnovy palcontologii 9: 55-64, Isdatelstwo Akademija Nauk SSSR, Moskva.

Tschernova. O. A. \& Sinitschenkova. N. D. 1974. Novyi rod widiskolajemych podenok semeistwa Hexagenitidae (Ephemeroptera) s juga ewropeiskoi časti SSSR i ich swayaz s sowremennymi podenkami. - Entomologičeskoe obozrennije 53 (1): 130-136. St. Petersburg.

Uéno. M. 1935. A fossil insect nymph from Jehol. - Report of the First Scientific Expedition to Manchoukouo 1933, 2 (2): 8 pp.

Vakhrameev. V. A. 1958. Stratigrafija i iskolajemaja flora jursjkich i melowych otloschenii Wiljuiskoi wpadiny i prilegajuschčei časti Priwerchojanskogo krajewogo protiba. - Regionalnaja Stratigrafija SSSR 3: 136 pp., 32 pls.

Yabe. H. 1905. Mesozoic plants from Korea. - Journal of the College of Sciences, Imperial University, Tokyo 20 (8): 59 pp. 4 pls. 